


\title{
CHARACTERISTICS, STABILITY AND ANTIMICROBIAL ACTIVITY OF LACTIC ACID BACTERIA (Leuconostoc sp) ISOLATED FROM BROILER'S CAECUM DURING STORAGE
}

\author{
S. Sumarsih, B. Sulistiyanto and C. I. Sutrisno \\ Faculty of Animal Agriculture, Diponegoro University \\ Tembalang Campus, Semarang 50275, Central Java-Indonesia \\ Corresponding E-mail: ssumarsih71@gmail.com \\ Received November 15, 2011; Accepted February 10, 2012
}

\begin{abstract}
ABSTRAK
Bakteri asam laktat (BAL) merupakan mikrobia alami yang biasa digunakan sebagai agensia fermentasi. Tujuan penelitian adalah untuk mengkaji karakteristik, stabilitas dan sifat antimikrobia isolat bakteri asam laktat (Leuconostoc $s p$ ) yang diisolasi dari sekum ayam broiler selama penyimpanan. Penelitian menggunakan rancangan acak lengkap dengan 4 perlakuan (penyimpanan 0, 2, 4 dan 6 minggu) dengan 12 ulangan. Parameter yang diamati adalah total, kestabilan sifat bakteri asam laktat (Leuconostoc $s p$ ). Hasil penelitian menunjukkan bahwa total Leuconostoc sp nyata $(\mathrm{P}<0,05)$ menurun dari $8 \times 10^{7}$ menjadi $1 \times 10^{3}$ Colony Forming Unit (CFU)/mL selama penyimpanan. Isolat Leuconostoc $s p$ tetap stabil sifatnya selama penyimpanan. Aktivitas anti mikrobia Leuconostoc sp nyata $(\mathrm{P}<0,05)$ menurun dari 9,94 menjadi 8,68; 7,23 dan 6,14 mm selama 2, 4 dan 6 minggu penyimpanan.
\end{abstract}

Kata Kunci : bakteri asam laktat, Leuconostoc sp, penyimpanan, sekum ayam broiler

\begin{abstract}
Lactic acid bacteria (LAB) is one of the natural microbe which widely used as fermentation agents. The purpose of this study was to examine the characteristics, stability and antimicrobial properties of lactic acid bacteria (Leuconostoc sp) isolated from broiler's caecum during storage. This research was conducted by the Complete Randomized Design with 4 treatments (time of storage: 0, 2, 4 dan 6 weeks) with 12 replications. Parameters observed were total number and stability properties of Leuconostoc sp isolate which known as lactic acid bacteria. The results obtained total number of Leuconostoc sp isolate were significantly $(\mathrm{P}<0.05)$ decreased from $8 \times 10^{7}$ to $1 \times 10^{3}$ Colony Forming Unit $(\mathrm{CFU}) / \mathrm{mL}$ during storage. Stability properties of Leuconostoc sp isolate were not affected by the time of storage. Antimicrobial activity of Leuconostoc $s p$ were significantly $(\mathrm{P}<0.05)$ decreased from 9.94 to 8.68, 7.23 and $6.14 \mathrm{~mm}$ during storage at 2, 4 and 6 weeks.
\end{abstract}

Key Words: lactic acid bacteria, Leuconostoc sp, storage, broiler's caecum

\section{INTRODUCTION}

Lactic acid bacteria (LAB) is one of the natural microbe that is widely used as fermentation agent. Their capabilities in lowering $\mathrm{pH}$ due to the lactic acid produced could give a beneficial effect to the fermented product. The process of fermentation by $\mathrm{LAB}$ are depend on activities and proliferation of bacteria, lactic acidproducing bacteria (Rahayu, 2003).

Based on their characteristics, LAB are characterized as Gram positive, usually nonmotile, non-sporulating bacteria that produce lactic acid as a major or sole product of fermentative metabolism (Malaka and Laga, 2005). Classified LAB can be isolated from temperate regions according to their morphology, physiology and molecular characters (Holt et al., 1999).

Lactic acid-forming organisms are divided into two species, namely: 1) homofermentatif species capable of changing form the $95 \%$ lactic acid, 2) heterofermentatif species, a group that produces lactic acid in small amounts and the resulting product is ethyl alcohol, acetic acid, formic acid and carbon dioxide (Fuller, 2001). Lactic acid bacteria on fermentation of carbohydrates produce lactic acid which can 
lower the $\mathrm{pH}$. The decrease of $\mathrm{pH}$ can inhibit the growth of other microorganisms, particularly bacterial pathogens (Huang et al., 2004). The potency of $\mathrm{LAB}$ to inhibit the growth of pathogenic bacteria is caused by the availability of antimicrobial compound, especially lactic acid.

Current research on fermentation process showed that LAB is known to play a role in the process of fermentation and preservation of food (Rahayu, 2003). Pediococcus acidilactici F-11 is known to produce bacteriocin as biocontrol agent E. Coli and S. aureus (Rahayu et al., 2004). Lactobacillus sp and Leuconostoc sp were LAB with potential as probiotics (Purwandhani and Rahayu, 2003) and its stability can be maintained during storage by dry cell preparation as a probiotic powder (Hartati and Harmayani, 2006).

Lactic acid bacteria are also known as the hypercholesterolemia prevention agent reflected in increased HDL cholesterol and LDL cholesterol reduction in Winstar rat (Harmayani, 2002) and broiler (Sumarsih et al., 2010). Acid-producing microbe in chicken manure is known comes from the caecum (Harimurti et al., 2005). Lactic acid bacteria (Lactobacillus $s p$ and Leuconostoc sp) can be used as a probiotic isolated from broiler intestinal tract. The Leuconostoc spesies has been considered as a potential pathogen especially initial immunocompromized host (Ling, 1992).

There are many technological challenges in the development of $\mathrm{LAB}$ as fermentation agent. These challenges include selection of LAB, levels of addition, safety consideration, processing effect on viability, enumeration, storage stability and sensory impact. LAB isolate can be stored before used as a starter and probiotic. Storage isolates simplest way for investment in the medium or liquid medium and stored at low temperature. There are many extrinsic and intrinsic factors that affect stability of probiotics during storage, including acidity $(\mathrm{pH})$, temperature, oxygen, water activity, lack of nutrients, microbial antagonism, presence of inhibitors (Vasiljevic and Shah, 2008).

Numerous studies have been conducted on the stability of LAB and probiotics. Research in protection of LAB to maintain the viability and stability have been carried out, particularly using micro-encapsulation using several materials, such as $\mathrm{Ca}$ alginate and maltodextrin, as well as the methods of micro-encapsulation (Ngatirah et al., 2009; Banyuaji et al., 2009). Characteristic, stability and antimicrobial activity of LAB can change during storage (Champagne et al., 2008).
There is a need to understand and improve survival of these cultures during storage at refrigerated temperatures. Therefore, the objective of this study was to examine the characteristics, stability properties and antimicrobial activity of lactic acid bacteria isolated from broiler's caecum during storage.

\section{MATERIALS AND METHODS}

\section{Materials}

This investigation was conducted at Feed Technology Laboratory of Animal Agriculture Faculty, Diponegoro University. Materials were broiler's caecum and MRS medium (de-Mann Rogossa and Sharp). MRS agar consisted of $15 \mathrm{~g}$ of agar; $10 \mathrm{~g}$ of ocsoid pepton; $5 \mathrm{~g}$ of yeast extract; $2 \mathrm{~g}$ of $\mathrm{K}_{2} \mathrm{HPO}_{4} ; 2 \mathrm{~g}$ of diamonium sitrat; $20 \mathrm{~g}$ of glucosa; $1 \mathrm{~g}$ of tween $80 ; 5 \mathrm{~g}$ of natrium asetat; $0.58 \mathrm{~g}$ of $\mathrm{MgSO}_{4} .7 \quad \mathrm{H}_{2} \mathrm{O}, 0.28 \mathrm{~g}$ of $\mathrm{MnSO}_{4} \cdot \mathrm{H}_{2} \mathrm{O}, 10 \mathrm{~g}$ of meat extract and $1000 \mathrm{~mL}$ of aquadest.

\section{Isolation Methods}

Leuconostoc sp was isolated from broiler's caecum with MRS medium- $\mathrm{CaCO}_{3} 1 \%$ of added $10 \mathrm{ppm}$ Syclo-hexamide to suppress the growth of yeast and $10 \mathrm{ppm}$ of $\mathrm{Na}$ Azida to suppress microaerob (Rahayu, 2003). Broiler's caecum 10 $\mathrm{g}$ were taken aseptically and homogenized in 90 $\mathrm{ml}$ of $\mathrm{NaCl}$ solution. Serial dilution up to $10^{-7}$ were prepared and appropriate dilutions were plated onto MRS medium- $\mathrm{CaCO}_{3} 1 \%$ of added 10 ppm syclo-hexamide. All plates were incubated at $37^{\circ} \mathrm{C}$ for 48 hours. LAB can be observed from clear zones around the colonies which indicated the dissolving of $\mathrm{CaCO}_{3}$ by an acid.

\section{Identification Methods}

Identification of LAB based on morphological characters, biochemical and physiological. Morphological parameters included cell shape and coloring grams. Biochemical parameters was the catalase test. Physiological parameters included clear zone at colony of LAB. Cells form colonies of bacteria were observed in $\mathrm{LAB}$ isolates grown on MRS at room temperature for 2 - 3 days (Harimurti et al., 2005).

Gram staining method was conducted by coloring method (Seely et al., 2001). Catalase test was performed by dripping a solution of hydrogen peroxide on mikrobia culture, in which a positive 
reaction if the $\mathrm{CO}_{2}$ bubbles appear. Clear zone was observed in colonies of lactic acid bacteria isolates grown on MRS- $1 \% \mathrm{CaCO}_{3}$.

\section{Storage and Starter Preparation}

Storage of $\mathrm{LAB}$ isolates is done by entering in $0.1 \mathrm{ml}$ of isolates in MRS Broth medium in a test tube and stored on refrigerator at $10{ }^{\circ} \mathrm{C}$ temperature with storage time according to treatment. Culture Leuconostoc sp was entirely transferred to the erlenmeyer containing $50 \mathrm{~mL}$ of MRS Broth medium and then incubated at $37^{\circ} \mathrm{C}$ for 48 hours. Two drops of the incubated MRS Broth medium were inoculated into $10 \mathrm{~mL}$ of solution with $10 \%(\mathrm{w} / \mathrm{v})$ skim milk and has sterilized at a temperature of $12^{\circ} \mathrm{C}$ for 15 minutes. After incubation $37^{\circ} \mathrm{C}$ for 48 hours, the culture was used as parent culture.

The parent culture was inoculated into the same medium with the addition of $3 \%$ glucose. The culture was incubated $37^{\circ} \mathrm{C}$ for 24 hours in order to obtain working culture which was ready to be used.

The stability of LAB was measured by pour plate method using MRS agar. MRS agar was used for enumeration total Leuconostoc sp. One $\mathrm{mL}$ of appropriate serial dilutions of each sample was pour plate onto the sterile media. After $24 \mathrm{~h}$ incubation at $37^{\circ} \mathrm{C}$, the colonies that appeared on the plates were counted and the cfu/mL was calculated.

The antimicrobial activity of $\mathrm{LAB}$ against Escherichia coli was performed by the wall diffusion assay (Lade et al., 2006). Leuconostoc $s p$ culture were grown in MRS broth at $37^{\circ} \mathrm{C}$ for 24 hours. Escherichia coli were grown in nutrient broth at $37^{\circ} \mathrm{C}$ for 24 hours. Ten $\mathrm{mL}$ of nutrient soft agar inoculated by $50 \mu \mathrm{L}$ broth culture of Escherichia coli. MRS agar poured on petri dish and allow to solidity. Then overlaid with nutrient broth and in placed at a temperature of $4^{\circ} \mathrm{C}$ for 1 hour. Fifty $\mu \mathrm{L}$ of Leuconostoc $s p$ culture was filled and incubated at $37^{\circ} \mathrm{C}$ for 24 hours. Leuconostoc $s p$ gave clear zones when have antimicrobial activity against Escherichia coli. The diameter of the inhibition zone was measured.

\section{Parameters Measured and Statistical Analysis}

Experiment was conducted according to completely Randomized Design (CRD) consisting 4 treatments and 12 replications. The treatments applied were , T0 $=0$-week storage as control, $\mathrm{T} 1$,
T2 and T3 was time storage for 2, 4 and 6 weeks.

The observed parameters included the parameters of phenotypic characters of isolates of LAB (Seely et al., 2005), total LAB in accordance with the method Fardiaz (1993) and Characteristics of LAB's isolates during storage. The data were analyzed by variance (ANOVA) to determine the influence of treatment and further tests performed Duncan's Multiple Areas to know the difference between treatments (Steel and Torrie, 1981).

\section{RESULTS AND DISCUSSION}

Phenotypic characters of isolates could be observed from morphological, biochemical and physiological appearance of LABs colony (Holt et al., 1999). The LAB isolates were classified into the genera Streptococcus, Leuconostoc, Pediococcus and Lactobacillus based on their morphology and biochemical characters (Nair and Surendran, 2005). Table 1 shows phenotypic characters of Leuconostoc $s p$ isolate from broiler's caecum.

Twelve isolates (L1 to L12) appeared the coccus cells, positive to gram staining reaction, negative to catalase-test and there are Clearly Zone around the colony. It is strongly suspected for a genus of Leuconostoc (Ling, 1992; Harimurti et al., 2005).

Total numbers of LAB's during storage are presented in Table 2. Table 2 shows that the total numbers of LAB's decreased during storage. At 0 weeks of storage, the the total numbers of LAB's were highest. Isolates of Leuconostoc $s p$ stored at 0 week has a higher total number, that was $8 \times 10^{7}$ $\mathrm{CFU} / \mathrm{mL}$ compared to isolates of Leuconostoc $s p$ stored at 2, 4 and 6 weeks that only $2 \times 10^{6} ; 2 \times$ $10^{4}$ and $1 \times 10^{3} \mathrm{CFU} / \mathrm{mL}$. At 0 week of storage, the total leuconostoc $s p$ were highest. At 0 weeks storage conditions of lactic acid bacteria is still in the logarithmic phase of growth and cell division occurs very quickly with nutritional support growth media. Hartati and Harmayani (2006) stated that the logarithmic phase bacterial cells will grow and divide exponentially until the maximum number supported by environmental factors such as environmental conditions, nutrients and temperature.

Storage at week 2, 4 and 6 significantly $(\mathrm{P}<0.05)$ lower total number of Leuconostoc sp. Decreasing in the total number of Leuconostoc $s p$ due to the storage temperature of $10^{\circ} \mathrm{C}$ in 
Table 1. Phenotypic Characters of Leuconostoc sp Isolated from Broiler's Caecum

\begin{tabular}{ccccccccccccccc}
\hline & \multicolumn{11}{c}{ Characteristics } & \multicolumn{11}{c}{ Code of Isolate } \\
\cline { 2 - 13 } & L1 & L2 & L3 & L4 & L5 & L6 & L7 & L8 & L9 & L10 & L11 & L12 \\
\hline Coccus shape & + & + & + & + & + & + & + & + & + & + & + & + \\
Gram staining & + & + & + & + & + & + & + & + & + & + & + & + \\
Catalase test & - & - & - & - & - & - & - & - & - & - & - & - \\
Clearly Zone & + & + & + & + & + & + & + & + & + & + & + & + \\
\hline
\end{tabular}

Table 2. Total Numbers of LAB's During Storage

\begin{tabular}{lc}
\hline Time of Storage & Numbers of LAB's $(\mathrm{cfu} / \mathrm{g})$ \\
\hline 0 weeks & $8 \times 10^{7 \mathrm{a}}$ \\
2 weeks & $2 \times 10^{6 \mathrm{~b}}$ \\
4 weeks & $2 \times 10^{4 \mathrm{c}}$ \\
6 weeks & $1 \times 10^{3 \mathrm{~d}}$ \\
\hline
\end{tabular}

Different of superscripts in the same column indicates significantly difference $(\mathrm{p}<0.05)$

refrigerator was not fully inhibit the activity of the metabolism so that the availability of nutrients in the medium diminished and unable to support further growth of bacteria. Lidya and Djenar (2000) added that the death caused bacteria deteriorating environment mainly by the growing accumulation of toxic metabolic results of bacteria cells.

Stability of LAB is influenced by such of things as the number of early starters who were inoculated, the end result of fermentation metabolites harvesting, drying, osmotic pressure, oxygen availability, freezing and stress during the manufacturing processe of product (Siuta and Goulet, 2001). During storage, lactic acid which can lower the $\mathrm{pH}$ so it can affect cell viability. There was a linear relationship decrease in the number of cells microbe with decrease $\mathrm{pH}$ of growth media (Wang, 2005)

Temperature is a key factor that affects the stability of microorganism during storage (Lourens-Hattingh and Viljoen, 2001). Higher temperatures accelerate microbial metabolism which in impedes microbial survival (Liu and Tsao, 2010). LAB are exposed to a number of stress conditions, such as low and high temperature, low $\mathrm{pH}$ and low water activity, which cause membrane and cell wall damage, inhibition of active transport, retention of nutrients, morphological changes and loss of stability. Bacteria have developed adaptive strategies to face the challenges of changing environments, and to survive under conditions of stress (Abee and Wouters,1999). Stress adaptation of microbial cells enables the cells to survive better when they are subsequently exposed to the same stress or other types of stresses.

Lactic acid bacteria have been shown to induce adaptive response after exposing to some stresses.. Lactobacillus lactis ssp. lactis showed increased resistance to freezing stress at $10^{\circ} \mathrm{C}$ (Panoff et al., 1995). Bâati et al. (2000) reported that preincubation of Lactobacillus acidophilus at low temperature $\left(22^{\circ} \mathrm{C}\right)$ for $6 \mathrm{~h}$ led to development of cryotolerance during freezing treatment at $-80^{\circ} \mathrm{C}$ for $24 \mathrm{~h}$.

Total LAB can be maintained with respect to environmental conditions during storage. Shortterm storage of isolates stored in refrigerator temperature $4^{\circ} \mathrm{C}$ while in the long-term culture bacteria should get special treatment, for example by encapsulated (Hoog, 2005) or freeze dried (Kurtman et al., 2009).

Table 3 shows the stability of character of isolates that has been identified as the Leuconostoc sp. The characteristics LAB remained stable during storage until 6 weeks. Table 3 also shows that the isolates have coccus cells shape, a positive gram reaction, catalase test is negative and there was allegedly a clear zone. It was stated by Ling (1992) that Leuconostoc sp has the characteristics of coccus cells shape, gram-positive reactions, negative catalase test and produce lactic acid. Storaging at 6 weeks at $10^{\circ} \mathrm{C}$ temperature properties of Leuconostoc $s p$ remained stable due to the mutation did not occur 
Table 3. Characteristics of Leuconostoc sp during Storage

\begin{tabular}{|c|c|c|c|c|c|c|c|c|c|c|c|c|}
\hline \multirow{2}{*}{ Characteristics } & \multicolumn{12}{|c|}{ Code of Isolate } \\
\hline & I1 & $\mathrm{I} 2$ & $\mathrm{I} 3$ & I4 & I5 & I6 & $\mathrm{I} 7$ & I8 & I9 & $\mathrm{I} 10$ & I11 & $\mathrm{I} 12$ \\
\hline \multicolumn{13}{|l|}{0 weeks } \\
\hline Coccus shape & + & + & + & + & + & + & + & + & + & + & + & + \\
\hline Gram staining & + & + & + & + & + & + & + & + & + & + & + & + \\
\hline Catalase-test & - & - & - & - & - & - & - & - & - & - & - & - \\
\hline Clearly Zone & + & + & + & + & + & + & + & + & + & + & + & + \\
\hline \multicolumn{13}{|l|}{2 weeks } \\
\hline Coccus shape & + & + & + & + & + & + & + & + & + & + & + & + \\
\hline Gram staining & + & + & + & + & + & + & + & + & + & + & + & + \\
\hline Catalase-test & - & - & - & - & - & - & - & - & - & - & - & - \\
\hline Clearly Zone & + & + & + & + & + & + & + & + & + & + & + & + \\
\hline \multicolumn{13}{|l|}{4 weeks } \\
\hline Coccus shape & + & + & + & + & + & + & + & + & + & + & + & + \\
\hline Gram staining & + & + & + & + & + & + & + & + & + & + & + & + \\
\hline Catalase test & - & - & - & - & - & - & - & - & - & - & - & - \\
\hline Clearly Zone & + & + & + & + & + & + & + & + & + & + & + & + \\
\hline \multicolumn{13}{|l|}{6 weeks } \\
\hline Coccus shape & + & + & + & + & + & + & + & + & + & + & + & + \\
\hline Gram staining & + & + & + & + & + & + & + & + & + & + & + & + \\
\hline Catalase-test & - & - & - & - & - & - & - & - & - & - & - & - \\
\hline Clearly Zone & + & + & + & + & + & + & + & + & + & + & + & + \\
\hline
\end{tabular}

Table 4. The Antimicrobial Activity of LAB's During Storage

\begin{tabular}{lc}
\hline Time of Storage & $\begin{array}{c}\text { Average Diameter of Inhibitin } \\
\text { Zone of LAB's (mm) }\end{array}$ \\
\hline 0 weeks & $9.94^{\mathrm{a}}$ \\
2 weeks & $8.68^{\mathrm{b}}$ \\
4 weeks & $7.23^{\mathrm{c}}$ \\
6 weeks & $6.14^{\mathrm{d}}$ \\
\hline
\end{tabular}

Different of alphabetic superscripts in the same column means significantly difference $(\mathrm{p}<0.05)$

during storage bacteria cells. This result was similar to Kurtmann et al. (2009). According to Kurtmann et al. (2009), stability character of LAB can be maintained during storage. Test of inhibition of Leuconostoc $s p$ against the bacteria Escherichia coli showed that all isolates tested could inhibit the growth of Escherichia coli (Table 4). Table 4 shows that the antimicrobial activity of LAB's decreased during storage. Storage at week 2,4 and 6 significantly $(\mathrm{P}<0.05)$ lower antimicrobial activity of Leuconostoc $s p$. At 0 weeks of storage, the antimicrobial activity of LAB's were highest. Isolates of Leuconostoc $s p$ storage at 0 weeks has a wider zone of inhibition that is equal to $9.94 \mathrm{~mm}$ compared with isolates Leuconostoc $s p$ storage at 2, 4 and 6 weeks that only $8.68 ; 7.23$ and $6.14 \mathrm{~mm}$. These suggests that isolates Leuconostoc $s p$ storage at 0 weeks better able to inhibit the growth of Escherichia coli compare to other time of storage.

Lade et al. (2006) classifies bacterial isolates inhibitory zone on the growth of LAB in 3 criteria, namely moderate inhibition (covering in 
area $6-9 \mathrm{~mm})$, strong inhibition $(10-14 \mathrm{~mm}$ width) and very strong inhibition (15-18 $\mathrm{mm}$ of width). Inhibition test of Leuconostoc $s p$ isolated included in the criteria moderate inhibition.

The ability of Leuconostoc mesenteroides SM-22 and Pediococcus acidilactici F-11 could inhibit psikrofil and phatogen bacteria isolated from fresh meat and fresh milk (Rahayu et al., 2004). Antimicrobial substances produced by Lactic acid bacteria (LAB) are used in association with selective insensitive starter to inhibit competitive microflora (Scannell et al., 2000).

Nowroozil et al. (2004) stated that antibacterial activities were done by an agar spot in which only $14.3 \%$ of strains known to produce bacteriocin. The inhibitory effect was pointed to bacteriocin not $\mathrm{H}_{2} \mathrm{O}_{2}$ since there was no oxidizing effect on bacterial cells which will destroy the basic molecular structure of cell proteins (Zalan et $a l ., 2005)$ and bacteriocin form the pores in the membrane of sensitive cells and deplete the transmembrane potential and/or the $\mathrm{pH}$ gradient, resulting in the leakage of cellular materials (McAuliffe et al., 2001).

\section{CONCLUSION}

Total number of lactic acid bacteria (Leuconostoc sp) isolated from broiler caecum decreased in line with the time of storage. The characteristics of lactic acid bacteria (Leuconostoc $s p$ ) isolate remain stable during $6^{\text {th }}$ week of storage. Antimicrobial activity of Leuconostoc $s p$ were decreased during storage.

\section{REFERENCES}

Abee, T. and J. A. Wouters. 1999. Microbial stress response in minimal processing. International Journal of Food Microbiology 50:65-91

Bâati, L., C. Fabre-Gea, D. Auriol, and J. P. Blance, 2000. Study of Cryotolerance of Lactobacillus acidophilus: Effect of Culture and Freezing Conditions on the Viability and Cellular Protein. International J. Food Microbiol. 59:241-247.

Banyuaji, A., E.S. Rahayu and T. Utami, 2009. Viabilitas Lactobacillus acidophilus SNP 2 dalam kapsul dan aplikasinya dalam es krim. J. Agritech. 29(1):171-178
Champagne, C. P. and N. J. Gardner. 2008. Effect of storage in a fruit drink on subsequent survival of probiotic lactobacilli to gastro-intestinal stresses. J. Food Research International 41:539-543.

Fardiaz, S. 1993. Mikrobiologi Pangan I. Gramedia Utama, Jakarta.

Fuller, R. 2001. The chicken Gut Microflora and Probiotic Supplements. J. Poult. Sci. 38:189 $-196$

Harmayani, E. 2002. Cholesterol reduction effect of probiotic cultures. Proceeding of The 2 nd Indonesian Biotechnology Conference. P.302-308

Hartati, S and E. Harmayani. 2006. Preparasi sel kering Lactobacillus sp DAD 13 dan kestabilannya sebagai bubuk Probiotik. J. Mikrobiologi Indonesia 11(1):1-4

Harimurti, S., E. S. Rahayu, Nasroedin and Kurniasih. 2005. Bakteri asam laktat dari intestin ayam sebagai agensia probiotik. Anim. Prod. 9(2):82-91

Holt, J. G., N. R. Krieg, P. H. A. Sneath, J. T. Staley and S. T. Willem. 1999. Bergey's Manual of Determinative bacteriology. $9^{\text {th }}$ Edition. Will \& Wilk. Baltimore, p 3-6

Hoog, S. 2005. Esencial Microbiology. John Wiley and Sons Ltd, Chichester

Huang, M. K., Y. J. Chory, R. Honde, J. W. Lee, B. Lee and X. Xhao. 2004. Effect of lactobacilli and a acidophilic fungus on the production performance and immune responses in broiler chicken. J Poult. Sci. 83: $788-795$

Kurtmann L., Carlsen, J. Risbo and L. H. Skibsted 2009. Storage stability of freezedried Lactobacillus acidophilus (La$5)$ in relation to water activity and presence of oxygen and ascorbate. Cryobiology 58:175-180.

Lade, H. S., M.P. Chitanand, G. Gyananath and T. A. Kadam. 2006. Studies on some properties of bacteriocins produced by Lactobacillus species isolated from agro-based waste. The Internet J. Microbiol. 2(1):1937-8289

Ling, M. L. 1992. Leuconostoc bacteraemia. J. Singapore Med. 33: 241-243

Liu, S and M. Tsao. 2010. Enhancing stability of lactic acid bacteria and probiotics by Williopsis saturnus var.saturnus in fermented milks J. Nutr. Food Sci. 40(3):314-322

Lourens-Hattingh, A. and B. C. Viljoen. 2001. Yoghurt as probiotic carrier food. 
International Dairy J. 11:1-17

Malaka, R and A. Laga. 2005. Isolasi dan identifikasi Lactobacillus Bulgaricus strain Ropy dari yogurt komersial. J. Sains dan Teknologi. 5 (1):50-58

McAuliffe, O., R. P. Ross and C. Hill. 2001. Lantibiotics: Structure, biosynthesis and mode of action. FEMS. Microbiol. Rev. 25: 285-308.

Nair, P. S. and P. K. Surendran. 2005. Biochemical characterization of lactic acid bacteria isolated from fish and prawn. J. Culture Collection. 4:48-52

Ngatirah, M. Ulfah and P.T. Dino. 2009. Characterization of encapsulated Lactobacillus Dad-13 with several type and concentration of encapsulan materials. Proceeding Seminar on Lactic Acid Bacteria and Culture Collection, 16-17 January, 2009, Yogyakarta. P 42-54.

Nowroozi1, J., M. Mirzaiil and M. Norouzi. 2004. Study of Lactobacillus as probiotic bacteria. Iranian. J. Publ. Health. 33(2):1 -7.

Panoff, J. M., B. Thammavongs, J. M. Laplace, A. Hartke, P. Boutibonnes and Y. Auffry. 1995. Cryotolerance and cold adaptation in Lactococcus lactis subsp. lactis IL1403. Cryobiology. 32:516-520.

Purwandhani, S. N. and E. S. Rahayu. 2003. Isolasi dan seleksi Lactobacillus yang berpotensi sebagai agensia probiotik. Agritech. 23(2): 67-74.

Rahayu, E. S. 2003. Lactic acid bacteria in fermented food of Indonesian origin. Agritech. 23(2):75-84

Rahayu. E. S., E. Harmayani, T. Utami and K. Handini. 2004. Pediococcus acidilactici $F$ 11 penghasil bakteriosin sebagai agensia biokontrol E. Coli dan S. aureus pada Sayuran Segar Simpan Dingin. Agritech. 24 (3):113-124

Scannell, A.G.M., R. P. Ross, C. Hill and E. K. Arendt. 2000. An effective lacticin biopreservative in fresh pork sausage. J. Food. Prot. 63:370-375.

Seely, H. W., P. W. Vanden Mark and J. J. Lee. 2001. Microbes in Action. A Laboratory Manual of Microbiology. 4 th Ed. W. H. Freeman and Comp. New York, p. 145 146.

Siuta, P. and J. Goulet. 2001. Improving probiotic survival rates (microencapsulation preserves the potency of probiotics microorganism in food system. Food Technol. 55(10):36-42.

Steel, R. G. D. and J. H. Torrie. 1981. Principles and Procedures of Statistics. McGraw-Hill Company Inc., New York

Sumarsih, S., T. Yudiati, C. S. Utama, E. S. Rahayu, E. Harmayani. 2010. The influence of using fish fermented by lactic acid bacteria as feed substitution on serum lipid profile of broilers. J. Indonesian Trop. Anim. Agric. 35(2):125-128

Vasiljevic, T. and N. P. Shah. 2008. Probiotics from Metchnikoff to bioactives. International Dairy J. 18:714-728

Wang, Y., G. Corrieu and C. Beal. 2005. Fermentation $\mathrm{pH}$ and temperature influence the cryotolerance of Lactobacillus acidophilus RD758. J. Dairy Sci. 88:21-29

Zalan, Z., E. Nemeth, A. Barath and A. Halasz. 2005. Influence of Growth Medium on Hydrogen Peroxide and Bacteriocin Production of Lactobacillus strains. Food Technol. Biotechnol. 43(3):219-25 